\title{
Treatment of Acute Hepatitis C
}

\author{
İlkay Bozkurt, Mustafa Sünbül \\ Department of Clinical Microbiology and Infectious Diseases, Ondokuz Mayis University School of Medicine, Samsun, Turkey
}

\begin{abstract}
An acute hepatitis $\mathrm{C}$ virus (HCV) infection is an uncommonly encountered illness. Patients infected with the HCV commonly tend to be asymptomatic because of spontaneous viral clearance or chronic infection. Early antiviral treatment may be beneficial especially in symptomatic cases. Antiviral therapy with an (IFN)-based regimen is standard except in the instance of a human immunodeficiency virus (HIV) coinfection. The efficacy of HCV therapy has been restricted by the side effects of treatment. Advances in the treatment options of chronic HCV infection have resulted in the development of many new antiviral drugs that may allow for simplified and shortened treatments with increased tolerability and efficacy in patients with acute HCV infection. J Microbiol Infect Dis 2016;6(1): 40-44
\end{abstract}

Key words: Acute hepatitis $C$, treatment, genotype, interferon, ribavirin

\section{ÖZET \\ Akut Hepatit C Tedavisi}

Akut Hepatit C virus (HCV) enfeksiyonu nadir görülen bir hastalıktır. Hastaların büyük bir kısmı asemptomatik seyretmektedir. HCV ile enfekte olan hastalar virüsü ya spontan olarak temizler veya kronik bir enfeksiyona ilerleyiş söz konusudur. Semptomatik olan hastalarda büyük oranda spontan viral klirens gelişir. Buna karşın asemptomatik hastalarda spontan klirens ihtimali daha düşüktür ve erken antiviral tedaviden fayda görürler. HIV koinfeksiyonu gibi durumlar dışında interferon bazlı rejimler standart antiviral tedavinin temelini oluştururlar. Tedaviden kaynaklanan ciddi yan etkiler HCV tedavisinin etkinliğini büyük ölçüde sınırlamıştır. Kronik HCV enfeksiyon tedavisi alanındaki yoğun çalışmalar sonucunda yeni birçok antiviral ajan geliştirilmiştir. Bu yeni ilaçlar çok daha etkili ve daha iyi tolere edilebildiğinden kronik HCV tedavisi eskiye oranla daha basit ve daha kısa süreli hale gelmiştir.

Anahtar kelimeler: Acut hepatit C, tedavi, genotip, interferon, ribavirin

\section{INTRODUCTION}

The annual incidence of the acute hepatitis $\mathrm{C}$ virus $(\mathrm{HCV})$ has decreased in recent years, due to effective and comprehensive blood screening practices and increased education programs of high risk groups [1]. An acute HCV infection may be occurred via exposure to the virus through different sources, such as a blood transfusion, injection drug use, sexual transmission, nosocomial transmission, occupational exposures, and inter familial exposure [1]. The greatest risk is related to repeated parenteral exposures in intravenous drug users. HCV transmission risk is lower via needle stick injuries in which health care workers are exposed to the blood or bloody fluids of patients infected with HCV. Despite the transmission rate is low in heterosexuel couples, exposure risk is much higher among HIV infected men who have sex with men [2]. The route of transmission may be related to economic conditions, particularly in developing countries in which $\mathrm{HCV}$ infection is primarily associated with healthcare-related procedures [1].

For the diagnosis of an acute HCV infection, the presence of both negative HCV antibody and positive HCV ribonucleic acid (RNA) test are required. Besides this positive HCV antibody test after a prior negative $\mathrm{HCV}$ antibody test results indicate acute HCV. [3] Monitoring HCV RNA (every 4 to 8 weeks) for 6 months is recommended to determine spontaneous clearance of the HCV infection versus the persistence of infection [4]. Symptomatic identification of patients with an acute HCV infection is uncommon due to its asymptomatic nature [5]. Patients infected with HCV may spontaneously clear the virus or proceed to develop a chronic infection [6]. Several factors influence the treatment efficacy,

Correspondence: Illkay Bozkurt, Department of Clinical Microbiology and Infectious Diseases,

Ondokuz Mayıs University School of Medicine, Samsun, Turkey, Email: drilkaybozkurt@gmail.com Received: 07 August 2015, Accepted: 09 December 2015

Copyright (C) Journal of Microbiology and Infectious Diseases 2016, All rights reserved 
including the regimen, HCV genotype, duration and the initiation of therapy.

\section{NATURAL PROGRESSION OF THE DISEASE}

Nearly two thirds of individuals with an HCV infection develop a chronic infection, approximately $20 \%$ of patients with chronic infection can develop cirrhosis, and $4 \%$ will develop hepatocellular carcinoma [7]. In patients with recently acquired HCV infection may present either asymptomatically with mild constitutional symptoms or with an elevated liver function tests. Only $10 \%-15 \%$ of patients are presented with jaundice $[5,7]$. HCV RNA could be detected within the first two weeks of exposure. 2-6 months or later seroconversion can be detected particularly in high risk populations. During the acute phase of the infection spontaneous clearance is possible [6]. The diagnosis of an acute HCV infection in the presence of an HIV coinfection is often obscured, because the acute HCV infection is more often asymptomatic when compared with HIV-negative patients. Therefore mild elevations in ALT levels should be observed particularly in high risk groups [8].

\section{TIMING OF TREATMENT}

Determination of the appropriate timing of therapy in patients with acute hepatitis is difficult, because the exact onset of the disease often cannot be determined accurately except in cases, such as needle stick injuries or unprotected sexual contact, in which the exact time of exposure is known. According to some authors, the presence of ALT elevation with or without clinical manifestations, may be the ideal time for initiating appropriate treatment $[9,10]$. Hofer et al proposed that patients should be monitored for HCV RNA with four times over a 12-week period, and patients who remain HCV positive at 12 weeks should receive antiviral treatment [11]. Delaying treatment for 12 weeks helps to avoid unnecessary treatment in patients. In a meta-analysis of 22 studies with 1,075 patients, patients treated within 12 weeks of diagnosis had higher sustained virologic response (SVR) rates than those who initiated treatment between 12 and 24 weeks, or after 24 weeks ( $83 \%$ versus $67 \%$ and $63 \%$, respectively) [12]. Initiating therapy earlier than 12 weeks does not appear to be efficacious. Licata et al. demonstrated that delaying the initiation of therapy by 8 to 12 weeks did not decrease the SVR rates [13]. In a study regarding acute HCV treatment, 129 patients were assigned to treatment with pegylated (Peg)IFN starting at week 8,12 , or 20 , and an SVR was achieved by $95 \%, 93 \%$, and $77 \%$ of patients, respectively. No benefit was determined for initiating treatment at 8 weeks compared with 12 weeks for patients with genotypes 2,3 , or 4 , although a higher SVR rate was observed in patients with genotype 1 who began treatment at week 8 compared with week 12 [14]. In a randomized, open-label trial including 132 patients with an acute HCV infection, Deterding et al. found the potential benefit of therapy on viral clearance initiated after 12 weeks [15]. Initiation of treatment after 12 weeks may not be inferior to immediate therapy. Treatment approach of patients with acute hepatitis $C$ is demonstrated in Figure 1.

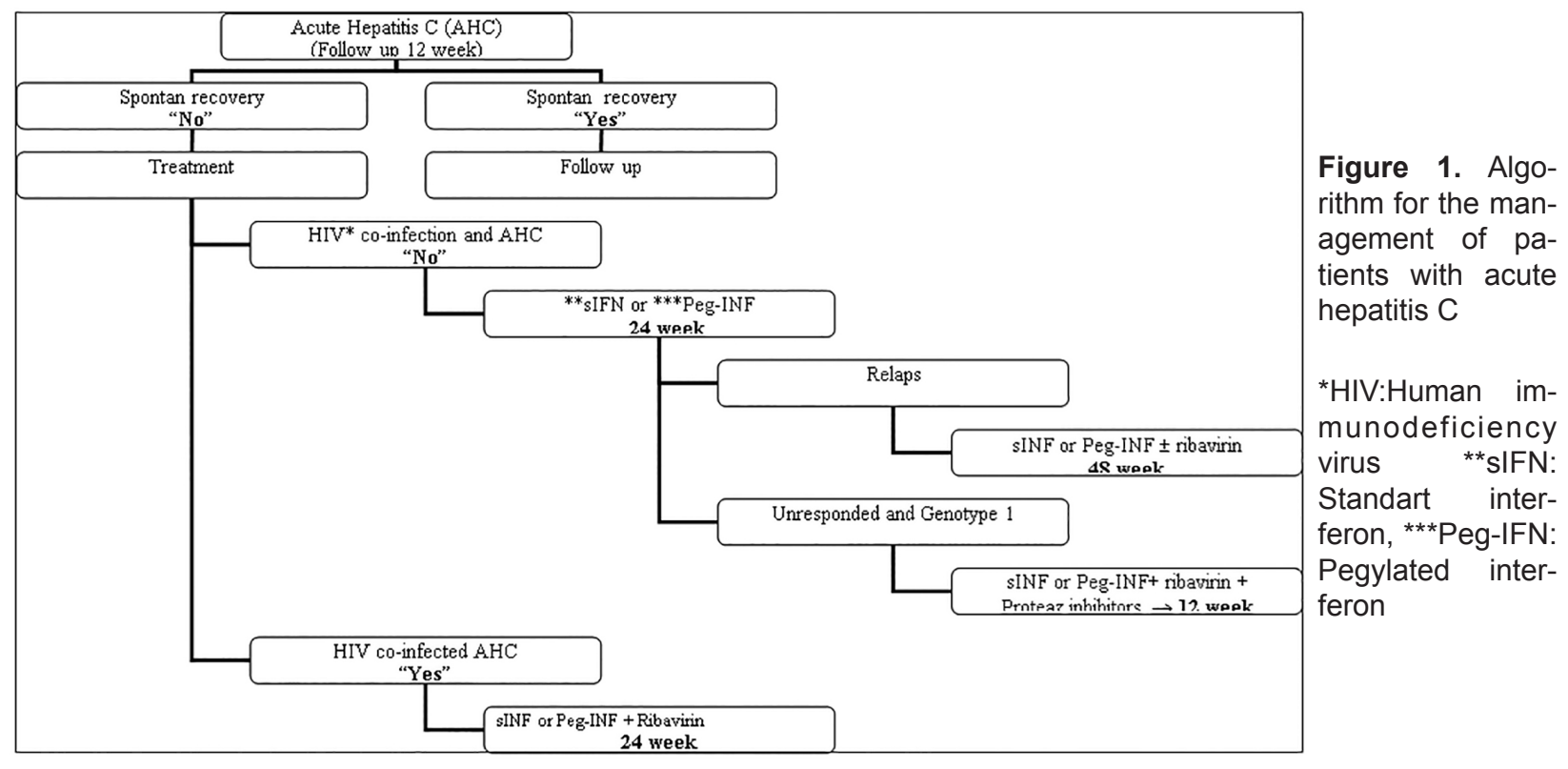




\section{INDIVIDUALIZATION OF THERAPY}

Patients must be keen on following the therapeutic regimen, because nonadherence is associated with significant decreases in SVR rates $[15,16]$. If the patient has certain comorbid conditions, such as a severe depressive illness that is contraindicated in IFN-based therapy, he or she may not be an appropriate candidate. Additionally, intravenous drug users are difficult to treat because of weak adherence to therapy [17].

To improve sustained response rates to IFNbased therapy, drug dose and treatment duration should be modified according to the needs of the patient. Kamal et al. demonstrated that patients with an acute HCV infection who do not have genotype 1 had higher rates of SVR [14]. Virologic response was occurred respectively in $60 \%$ and $88 \%$ of genotype 1 patients, and in $93 \%$ and $100 \%$ of genotype 4 patients, after 12 or 24 weeks of therapy. SVR rates could be predicted according to the rapid virologic response rates [18].

Different factors influence treatment outcomes, such as baseline clinical condition, patients ethnicity, adherence to treatment, genotype, and intravenous drug usage history. Therefore, well designed, comprehensive prospective research is needed to clarify the impact of pretreatment and on-treatment viral kinetics of acute HCV infection and to determine the onset, drug choice, and duration of the appropriate drug regimen [1].

\section{TREATMENT OPTIONS}

Acute HCV infection should be managed properly because it appears to represent a chance to prevent progression to chronic hepatitis $C$ disease [18]. Early diagnosis and also treatment of an acute HCV infection is likely to decrease the burden of chronic hepatitis, particularly infection with genotype 1 [19]. Additionally, the efficacy of the treatment of acute $\mathrm{HCV}$ infection was superior to the treatment of chronic infection [20].

High response rates (>90\%) were reported with Peg-IFN- $\alpha$ monotherapy, especially in symptomatic patients, irrespective of the HCV genotypes. In these cases Peg-IFN- $\alpha$ and ribavirin combination does not increase the SVR rate. However this therapy option may be beneficial in patients existing other negative predictors [15,21]. Wiegand et al. reported that treatment duration and SVR rates were independent of HCV genotypes [17].
In the literature, the efficacy of treatment for acute HCV ranged from $22 \%$ to $98 \%$ with standard IFN given daily or every three days $[10,22,23]$. A meta-analysis involving 141 patients with acute transfusion-acquired HCV infection treated with standard IFN monotherapy had a greater virologic response when compared with patients who were treated with a placebo or without treatment $(42 \%$ versus $4 \%)$ and a sustained virologic response $(32 \%$ versus $4 \%$ ) [24]. A higher SVR rate (98\%) with an IFN regimen was demonstrated in the study of Jaeckel et al. Peg-IFN may be preferable, because it is easier to administer and may be better tolerated [22]. Patients who are coinfected with HIV are the only group that may benefit from the addition of ribavirin therapy. In this patient group, SVR rates are too low with monotherapy [25]. Therefore, adding ribavirin to the regimen may increase SVR rates among patients with HIV infection, but it does not appear to improve outcomes in patients who are infected with HIV. The response rates with Peg-IFN given weekly vary from $57 \%$ to $95 \%[14,16,26]$. Although the data that support combining IFN or Peg-IFN with ribavirin are limited in the therapy of acute HCV, a significant advantage over monotherapy with Peg-IFN or standard IFN has not been demonstrated $[27,28]$. In a multicentered, randomized trial including 148 patients with acute HCV who remained viremic for 12 weeks following the onset of infection, administration of Peg-IFN for 24 weeks, Peg-IFN for 12 weeks, and Peg-IFN plus ribavirin for 12 weeks all resulted in similar SVR rates [28]. However, most studies suggest addition of ribavirin due to increased SVR rates in co-infected patients $[8,29]$.

Direct-acting antiviral agents have not been routinely recommended for the treatment of acute infection, because high SVR rates with IFN monotherapy and disadvantages of side effects with additional agents were observed. Fierer et al. examined combination therapy with telaprevir, Peg-IFN, and ribavirin compared with a standard dual regimen in HIV infected patients with an acute HCV infection and demonstrated higher SVR rates $(84 \%$ versus 63\%) [30].

Guidelines for treatment of acute HCV infections were proposed by the European Association for the Study of the Liver (EASL) that recommend Peg-IFN- $\alpha$ monotherapy (Peg-IFN- $\alpha 2 a 180 \mu \mathrm{g} /$ week or Peg-IFN- $\alpha 2 b 1.5 \mu \mathrm{g} / \mathrm{kg} /$ week, for 24 weeks) for patients with acute HCV infection regardless of HIV status. Additionally, patients who fail treatment with the standard treatment options may be retreated with or without ribavirin for 48 weeks. Protease 
inhibitor-based triple therapy, including telaprevir and boceprevir should be considered particularly for patients with genotype 1 who failed with standard antiviral therapy [4]. The duration of treatment regimen and response rate of patients with genotype 1 was shown in Table 1.

Table 1. Treatment regimen and response rate of patients with genotype 1

\begin{tabular}{ccccccc}
\hline $\begin{array}{c}\text { Numbe of } \\
\text { patients }\end{array}$ & $\begin{array}{c}\text { Spontaneous } \\
\text { recovery (No/\%) }\end{array}$ & $\begin{array}{c}\text { HCV } \\
\text { Genotype }\end{array}$ & Treatment regimen & $\begin{array}{c}\text { Duration of } \\
\text { therapy (weeks) }\end{array}$ & SVR Rate (\%) & Reference \\
\hline 17 & $0(0)$ & G1 (8/17) & Peg-IFN+ ribavirin & 24 & 100 & 36 \\
30 & $9(30)$ & G1 (13/26) & Peg -IFN \pm ribavirin & $22 \pm 5.7$ & 84.6 & 18 \\
25 & $5(20)$ & G1 (18/25) & Peg -IFN \pm ribavirin & 24 & 86.6 & 37 \\
117 & $51(44)$ & G1 (11/17) & Peg -IFN & 12 & 88.2 & 38 \\
19 & & G1 (11/19) & Peg -IFN & 12 & 73.6 & 19 \\
35 & $4(11)$ & G1 (20/32) & Peg -IFN+ ribavirin & $43(11-72)$ & 75 & 39 \\
175 & $27(15)$ & G4 (71/156) & Peg -IFN & 12 & 88.3 & 14 \\
24 & $7(29)$ & G1 (23/28) & Peg -IFN \pm ribavirin & $30.7 \pm 12$ & 93.7 & 26 \\
$(28$ episodes) & $7(17)$ & G1 (28/42) & Peg -IFN & 24 & 88.5 & 40 \\
42 & & & &
\end{tabular}

Recently, Pawlotsky suggested that drug regimens such as sofosbuvir with ledipasvir/simeprevir/ daclatasvir/ribavirin ( \pm Peg-IFN), ritonavir-boosted with paritaprevir, and ombitasvir \pm dasabuvir, which have demonstrated superiority over conventional therapy for treating chronic hepatitis $\mathrm{C}$, could be alternatives for treating acute HCV infection [31]. Recent treatment options for chronic hepatitis $C$ may present new alternatives that can be used as oral regimens with fewer side effects and increased tolerability and efficacy than IFN and ribavirin [32].

\section{VIRAL CLEARANCE}

An HCV infection is self-limiting disease and can spontaneously resolve during the acute period of the infection, or may result in chronic disease. Spontaneous clearance following acute HCV infection is $0-86 \%$ within the first 6 months following the infection; therefore, the acute phase of an HCV infection is defined as 6 months following the acquisition of an HCV infection [1,5,9,34]. Patients (\%11) who is still viremic at 6 months most probably will clear the virus in the next days [34].

Several factors are predictors of spontaneous viral clearance in the acute stage of the disease female gender, younger age especially children, elevated ALT levels, and acute clinical hepatitis C infection symptoms, particularly jaundice. Symptomatic patients presumably reflect a more effective host immune response which helps to eradicate virus by killing hepatocytes, is responsible for the clinical spectrum of the patients $[6,9]$. Low baseline viral load, rapid virologic response rates, being infected with non genotype-1 serotype could be associated with proper treatment outcomes [14]. Other predictors of spontaneous clearance include the presence of hepatitis B virus surface antigen (HBsAg) positivity and host genetic polymorphisms $[1,35]$. Host factors especially polymorphism of the IL28B gene can be related with spontaneous clearance $[18,19]$. However, none of these parameters certainly predicts the spontaneous resolution rate of the patients.

IFN based therapy is associated with various side effects, including hematologic, gastrointestinal, dermatological and psychiatric effects including suicide attempts and flu-like symptoms. The side effects of IFN-based regimens are the most encountered difficulties during therapy $[35,36]$.

\section{CONCLUSIONS}

An acute HCV infection is rarely encountered clinical condition because of asymptomatic nature of the disease and different rates of spontaneous resolution. Although new treatment options promise dramatic response rates in patients with chonic $\mathrm{HCV}$ infection, Peg-IFN-based regimen is still only recommended therapy approach in acute HCV infection.

Declaration of Conflicting Interests: No conflict of interest of any author exists.

Financial Disclosure: The authors declared no financial support. 


\section{REFERENCES}

1. Kamal SM. Acute hepatitis C: a systematic review. Am J Gastroenterol 2008;103:1283-1297.

2. Boesecke C, Rockstroh JK. Acute hepatitis $C$ in patients with HIV. Semin Liver Dis 2012;32:130-137.

3. Cox AL, Netski DM, Mosbruger T, et al. Prospective evaluation of community-acquired acute-phase hepatitis $\mathrm{C}$ virus infection. Clin Infect Di. 2005;40:951-958.

4. European Association for the Study of the Liver (EASL) Available from: URL: http://www.easl.eu/research/our-contributions/clinical-practice-guidelines/detail/management-of-hepatitis-c-virusinfection-revised-version/report/4.

5. Irving WL, Salmon D, Boucher C, et al. Acute hepatitis $C$ virus infection. Euro Surveill 2008;13:18879.

6. Thomas DL, Seeff LB. Natural history of hepatitis C. Clin Liver Di 2005;9:383-398

7. Chung RT. Acute hepatitis $C$ virus infection. Clin Infect Dis 2005;41:14-17.

8. Vogel M, Rockstroh JK. Treatment of acute hepatitis C in HIV infection. J Antimicrob Chemother 2010;65:4-9.

9. Micallef JM, Kaldor JM, Dore GJ. Spontaneous viral clearance following acute hepatitis $C$ infection: a systematic review of longitudinal studies. J Viral Hepa. 2006;13:34-41.

10. Gerlach JT, Diepolder HM, Zachoval R, et al. Acute hepatitis C:high rate of both spontaneous and treatment-induced viral clearance. Gastroenterology 2003;125:80-88.

11. Hofer $\mathrm{H}$, Watkins-Riedel $\mathrm{T}$, Janata $\mathrm{O}$, et al. Spontaneous viral clearance in patients with acute hepatitis $\mathrm{C}$ can be predicted by repeated measurements of serum viral load. Hepatology 2003;37:60-64.

12. Corey KE, Mendez-Navarro J, Gorospe EC, et al. Early treatmentimproves outcomes in acute hepatitis C virus infection: a meta-analysis. J Viral Hepat 2010;17:201-217.

13. Licata A, Di Bona D, Schepis F, et al. When and how to treat acute hepatitis C? J Hepatol 2003;39:1056-1062.

14. Kamal SM, Fouly AE, Kamel RR, et al. Peginterferon alfa- $2 b$ therapy in acute hepatitis C: impact of onset of therapy on sustained virologic response. Gastroenterology 2006;130:632-638.

15. Deterding K, Grüner N, Buggisch P, et al. Hep-Net Acute HCV-III Study Group. Delayed versus immediate treatment for patients with acute hepatitis $\mathrm{C}$ : a randomised controlled non-inferiority trial. Lancet Infect Dis 2013;13:497-506.

16. Broers B, Helbling B, François A, et al. Swiss Association for the Study of the Liver (SASL 18). Barriers to interferon-alpha therapy are higher in intravenous drug users than in other patients with acute hepatitis C. J Hepatol 2005;42:323-328.

17. Wiegand J, Deterding K, Cornberg M, et al. Treatment of acute hepatitis $C$ : the success of monotherapy with (pegylated) interferon alpha. J Antimicrob Chemother 2008;62:860-865

18. Deutsch M, Papadopoulos N, Hadziyannis ES, et al. Clinical characteristics, spontaneous clearance and treatment outcome of acute hepatitis C: a single tertiary center experience. Saudi J Gastroenterol 2013;19:81-85.

19. De Rosa FG, Bargiacchi O, Audagnotto S, et al. Dose-dependent and genotype-independent sustained virological response of a 12 week pegylated interferon alpha- $2 b$ treatment for acute hepatitis C. J Antimicrob Chemother 2006;57:360-363.

20. Ghany MG, Strader DB, Thomas DL, et al. American Association for the Study of Liver Diseases. Diagnosis, management, and treatment of hepatitis C: an update. Hepatology 2009;49:13351374.

21. Strader DB, Wright T, Thomas DL, et al. American Association for the Study of Liver Diseases. Diagnosis, management, and treatment of hepatitis C. Hepatology 2004;39:1147-1171.
22. Jaeckel E, Cornberg M, Wedemeyer H, et al. German Acute Hepatitis C Therapy Group.Treatment of acute hepatitis C with interferon alfa-2b. N Engl J Med 2001;345:1452-1457.

23. Lampertico P, Rumi M, Romeo R, et al. A multicenter randomized controlled trial of recombinant interferon-alpha $2 \mathrm{~b}$ in patients with acute transfusion-associated hepatitis C. Hepatology 1994;19:19-22.

24. Poynard T, Regimbeau C, Myers RP, et al. Interferon for acute hepatitis C. Cochrane Database Syst Rev. 2002;CD000369.

25. Serpaggi J, Chaix ML, Batisse D, et al. Sexually transmitted acute infection with a clustered genotype 4 hepatitis $C$ virus in HIV1-infected men and inefficacy of early antiviral therapy AIDS. 2006;20:233-240

26. Corey KE, Ross AS, Wurcel A, et al. Outcomes and treatment of acute hepatitis $C$ virus infection in a United States population. Clin Gastroenterol Hepatol 2006;4:1278-1282.

27. Nunnari G, Montineri A, Portelli V, et al. The useof peginterferon in monotherapy or in combination with ribavirin for the treatment of acute hepatitis C. Eur Rev Med Pharmacol Sci 2012;16:10131016.

28. Santantonio T, Fasano M, Sagnelli E, et al. Acute Hepatitis C Study Group. Acute hepatitis C: a 24-week course of pegylated interferon $a-2 b$ versus a 12-week course of pegylated interferon $a-2 b$ alone or with ribavirin. Hepatology. 2014;59:2101-2109.

29. Dominguez S, Ghosn J, Valantin MA, et al. Efficacy of early treatment of acute hepatitis $C$ infection with pegylated interferon and ribavirin in HIV-infected patients. AIDS 2006;20:1157-1161.

30. Fierer DS, Dieterich DT, Mullen MP, et al. New York Acute Hepatitis C SurveillanceNetwork. Telaprevir in the treatment of acute hepatitis C virus infection in HIV-infected men. Clin Infect Dis 2014;58:873-879.

31. Pawlotsky JM. Hepatitis C treatment: the data flood goes onan update from the liver meeting 2014. Gastroenterology 2015;148:468-479.

32. Hullegie SJ, Arends JE, Rijnders BJ, et al. Current knowledge and future perspectives on acute hepatitis $\mathrm{C}$ infection. Clin $\mathrm{Mi}-$ crobiol Infect 2015;21:797.

33. Hajarizadeh B, Grebely J, Dore GJ. Case definitions for acute hepatitis C virus infection: a systematic review. J Hepatol 2012;57:1349-1360.

34. Grebely J, Page K, Sacks-Davis R, et al. In C3 Study Group. The effects of female sex, viral genotype, and IL28B genotype on spontaneous clearance of acute hepatitis $\mathrm{C}$ virus infection. Hepatology 2014;59:109-120.

35. Mosley JW, Operskalski EA, Tobler LH, et al. Transfusiontransmitted Viruses Study and Retrovirus Epidemiology Donor Study Groups. The course of hepatitis $C$ viraemia in transfusion recipients prior to availability of antiviral therapy. J Viral Hepat 2008; 15:120-128.

36. Tomkins SE, Rice BD, Roy K, et al. Universal treatment success among healthcare workers diagnosed with occupationally acquired acute hepatitis C. J Hosp Infect 2015;89:69-71.

37. Loomba R, Rivera MM, McBurney R, et al. The natural history of acute hepatitis $C$ : clinical presentation, laboratory findings and treatment outcomes. Aliment Pharmacol Ther 2011;33:559-565.

38. Sharaf Eldin N, Ismail S, Mansour H, et al. Symptomatic acute hepatitis $C$ in Egypt: diagnosis, spontaneous viral clearance, and delayed treatment with 12 weeks of pegylated interferon alfa-2a. PLoS One. 2008;3:e4085.

39. Ishikane M, Watanabe $\mathrm{K}$, Tsukada $\mathrm{K}$, et al. Acute hepatitis $\mathrm{C}$ in HIV-1 infected Japanese Cohort: single center retrospective cohort study. PLoS One 2014;9:e100517.

40. Liu CH, Liang CC, Liu CJ, et al. Pegylated interferon alfa-2a monotherapy for hemodialysis patients with acute hepatitis $\mathrm{C}$. Clin Infect Dis 2010;51:541-549. 